\title{
Contribution of Social Media to the Students' Academic Development
}

\author{
Halil Ibrahim Gurcan
}

\begin{abstract}
Social media, throughout the communication world after 2005, has brought about the transformation of personal and social changes, specifically, among youngsters between the ages of 13 to 25 who use the social media intensely as a communication tool. Such an effect of social media is of great significance in terms understanding how they are utilized in courses and how students benefit from them in their learning processes. In this study, the case of sharing the social media will be put forward with regard to the relationship of teachers and students, that is to say, how they carry out their media facilities for their courses and learning/teaching processes will be under the focus.
\end{abstract}

Index Terms-Social media, students and teachers, social media education, technology usage.

\section{INTRODUCTION}

Social Media, throughout the communication world after 2005 , has brought about the transformation of personal and social changes, specifically, among youngsters between the ages of 13 to 25 who use the social media intensely as a communication tool.

Such an effect of social media is of great significance in terms understanding how they are utilized in courses and how students benefit from them in their learning processes.

There are many features of social media tools for the improvement of educational processes. Social media can be used in education processes for improving communication skills of students and teachers, expanding participation, empowering peer support, realization of collaborative learning. Social media also provides facilities which are enriching the learning and teaching processes with text, video, audio materials, supporting learning processes of students and supporting teachers' teaching and evaluation processes [1].

Boyd and Ellison [2] defined social network sites as public web-based services that allow users to develop a personal profile, identify other users ("friends") with whom they have a connection, read and react to postings made by other users on the site, and send and receive messages either privately or publicly. Individuals may choose to send private messages, write on other user's walls, organize social activities, and keep informed about other user's daily activities. However, users can limit themselves on what information they would like to share publicly with others. Some items they may choose to include are: pictures, favorite books and movies,

Manuscript received May 3, 2014; revised August 10, 2014.

Halil Ibrahim Gurcan is with the Anadolu University, Faculty of Communication Sciences, Eskisehir, CO 26470 Turkey (e-mail: higurcan@gmail.com). birthday, relationship status, and location [3].

Social network sites help fulfill communication needs and wants. It is a convenient method of communication and provides the ability to stay connected with friends and family, but on the users own rate and time [4]. Users can manage their interactions within their own schedule by choosing when they want to read and respond. The internet communication is a solitary activity usually done alone. However, it is efficient because it is a one-to-many method of communication which allows users to quickly spread information [5].

In this study, the case of sharing the social media will be put forward with regard to the relationship of teachers and students, that is to say, how they carry out their media facilities for their courses and learning/teaching processes will be under the focus.

Social media provides students a new mechanism for a familiar exercise: that of personal expression. Roughly 52 percent of the world's population is under 30 years old, and in the United States, 75 percent of this generation uses social media, based on a 2010 Pew Research Center study on the Millennial generation. College students make up a significant segment of that population [6]. Just as college students are using social media websites like Facebook and Twitter to share their social lives online, new social media tools are ways these students can share their academic work online as well. Here is a rundown of some social media tools college students can use to share everything from homework help to book rentals [7].

\section{What Is SOCIAL MEDIA?}

"Social media" is defined by Merriam-Webster as "forms of electronic communication (as web sites for social networking and microblogging) through which users create online communities to share information, ideas, personal messages, and other content" [8].

Social media is a defining component of Web 2.0, the term given to the information technology that permits users to be active creators and sharers of online information, rather than simply absorbers of information. Currently, the most popular examples of this technology include micro blogging (Twitter), social networking (Facebook, LinkedIn), wikis (Wikipedia), multimedia (YouTube), presence apps (Foursquare).

This is a limited list that is bound to change quickly, likely precipitated by our own students' contributions to the field. Instead of trying to master the nuances of each application that arrives on the scene, practitioners would do well to understand the impact of, and basic legal issues associated 
with, social media [9].

\section{A. Should Institutions Monitor Student Use of Social Media Sites?}

Institutions may be tempted to monitor social media sites for misconduct or evidence of possible danger to students or others. Putting aside the issue of potential liability associated with such activity, it would likely prove impossible given the number of social media sites currently available to students. Instead, institutions should consider more targeted and strategic investigations of social media use such as to investigate reports of potentially actionable behavior. Also, different rules may apply to school-sponsored blogs or other social media sites as opposed to purely personal websites and postings. Whichever approach they decide upon, institutions should create an internal protocol that most appropriately fits the needs and interests of their campuses and then follow it consistently [9].

\section{B. Can Colleges and Universities Sanction Students in} Response to Student Speech Posted on Social Media Sites?

The issue of inappropriate, controversial or contentious student speech on campus communities is not a new one, but online speech adds to the challenge for a number of reasons. First, the speech occurs online, where a much broader audience can potentially access it compared with typical on-campus speech. Also, layers of student-imposed privacy may exist online; as a result, institutions often acquire knowledge of student online speech because of another student who has access to the speech. Finally, online speech exists, it's hard to know when to respond. As with any inappropriate student behavior, administrators can and should respond to inappropriate online speech, although the specific response should vary depending upon the type of speech encountered [9].

\section{SOCIAL MEdIA AND PERSONAL EXPRESSION}

Social media provides students a new mechanism for a familiar exercise: that of personal expression. It gives students an instant forum by which to publicly evaluate and comment on their campus environments, institutional policies, classes, professors, administration and fellow students in real-time. Like a high-speed rail, social media zips through our campuses nearly unseen, dragging behind it the heavy weight of social injustices and complicated jurisprudence accumulated from decades of student speech. Given social media's potential for positive impact, no one is suggesting we pull the breaks on it, and in many ways the technology is already out of our grasp [10].

Student-teacher interaction is a constant part of the school day. Today's students communicate via technology, and that "If you say absolutely no Facebook or texting, you are cutting off an important relationship with students [11].

As an online teacher...use of technology is key.... a teacher use a variety of tools...skype, text, email, facebook and twitter... These are all ways a teacher helps communicate and helps students, as well as, their parents. There is always the ability for bad things to happen with or without the use of technology. Students today are embrasing the technology...In order to meet their needs educationally we must embrace the technology and ad. [11].

Students use social media to communicate with their teachers as a group outside of class and to plan school events and what not.

Social media is also used by teachers to show students videos and articles related to their classes that they may find interesting.

It also allowed students to get help on school work from teachers during the evening, weekends, and holidays so that they never fell behind.

The cell phone numbers are used for safety on field trips as well as another way to get in touch with teachers quickly during the school day, if a student is going to be late or absent or outside of school in an emergency.

People need to stop worrying about what could go wrong and realize that there is a huge opportunity here to extend the learning experience for kids, and isn't that what it's all about. There is always the potential for things to go wrong, and that is true before technology as well [11].

\section{Potential Risks FOR SOCIAL MEDia}

Regarding the number of complaints of inappropriate contact involving social media, the potential risks are too great. Any one-on-one private relationship out of the classroom begs for inappropriate behavior to begin.

One method of ensuring that students understand appropriate technology use is a clear and comprehensive Technology Use Policy. Some examples of items to include in a Technology Use Policy can include: [11]

Users shall be courteous and respectful of others.

Profanity, vulgarity, obscenity, or language that is harassing, derogatory, or otherwise inappropriate for the school environment is not permitted.

Users shall not display, send, retrieve, or download any items that are sexually explicit, or contain hate-based or discriminatory material. Users shall notify a teacher or school administrator in the event inappropriate material is inadvertently accessed.

Users acknowledge that they have no right or expectation of privacy with respect to their use of school technology.

School administration and IT personnel can retain the right to access and monitor the activities and files of all users, at any time, and for any reason.

The use of school technology is a privilege and may be revoked at any time by the school administration for violation of this policy or for engaging in any inappropriate use of school technology.

There are ways to use social media and ways not to- make sure you know the differences.

There's more to using social media tools than just quick updates and playful banter among friends. Sure, you can post pictures on Facebook, tell friends what you're doing via Twitter, and upload videos of your roommates doing something crazy to YouTube. But social media can be useful, too. Many students use online learning system (like Blackboard's) — an online tool that allows professors to post assignments, schedules, questions, and more information while keeping the conversation with students going outside of class. Countless colleges and universities use the usual 
suspects like Facebook, Second Life, and Twitter to interact with students, and students can use those tools to enhance their online profile for employment purposes. Yet as much as these technological tools have become commonplace on campus, there's still a caveat: The Internet can be misused, and missteps can be costly [12].

\section{DO's AND DON'TS FOR SOCIAL MEDIA}

To help identify some do and don'ts for college students using social media, some key pointers for using social media [13]:

1) Do create positive content. A big part of what both Brand-Yourself and Syracuse talk about is making a good impression online. That doesn't just mean smiling in your Facebook profile picture; it means showing that you're interested in your prospective field. Post links to interesting stories. Jump into debates and conversations when it's appropriate. Make LinkedIn connections with recruiters and internship coordinators and join alumni networks, too.

For younger students, try to spread an even wider net. If you're a freshman, you probably aren't ready to commit to being a lawyer or marketing rep just yet, but you can use social media to interact with recent college graduates and professionals from multiple fields.

2) Don't post questionable photos of yourself anywhere on the Internet. Some companies direct their own employees and interns to snoop around and use all kinds of channels to get access to information.

3) Do Google yourself. Search for yourself. You might get made fun of, but knowing what's on the Internet when people look for you is very important. Part of Brand-Yourself's strategy is teaching its clients how to use search-engine optimization to their advantage. In other words, find out what terms and keywords you can use to make positive pieces of content about you show up. If you have a personal website or a blog, give it some bells and whistles and make it easily accessible.

4) Don't post negative status updates or tweets. Sometimes, it's hard to be positive. School is challenging. And the news hasn't exactly been buzzing with beaming faces and rainbows. But don't let that come out in your status updates. Never rip a classmate, coworker, or person in a leadership role like a professor or boss, and don't openly complain about your job, either. It just doesn't look good.

5) Don't make your online presence all about you. Don't post what you're eating for lunch. Don't put up status updates asking for jobs. You can make your presence known by being interactive. Share relevant articles and videos. Make thoughtful comments when you can. Retweet interesting posts from people you follow [13].

\section{INTERACT WITH STUDENTS}

It's a pressing issue first, because there have been several high-profile cases of inappropriate conduct, and second, because social media provides an opportunity to share relevant information to an entire class (or multiple classes) if it's handled well. Here are a few tips: [14].
Stay On Campus: If they're available on your campus, course management software like Blackboard, Banner or WebCT can do nearly everything Facebook can do and there's a "check" in place in that the school is able to oversee the interaction. In addition, it allows other students to view, participate in and learn from the interaction

Don't Friend-Be Friended: Faculty (and supervisors) should never initiate friend requests - they need to respect the fact that the power inherent in their position might make students fearful to refuse the request. If a professor wants to invite students to connect with them - it should be done in the form of a general invitation to the entire class (no different than providing their email in the syllabus).

Stay Public: Conduct discussions in the open (ie through wall posts as opposed to personal messages) to help ensure that they stay focused on the course and don't deviate into personal areas that might be inappropriate. It's the same as the principle behind conducting an after-class meeting with a student in a hallway as opposed to a classroom so that even the appearance of impropriety is avoided.

Use the Buddy System: It would be ideal if faculty would let their department head, dean or another colleague knows that they're using social media to interact with students and to "friend" them to give themselves a system of checks and balances. If you've got another pair of eyes helping you keep tabs on what you're doing, they may be able to help you watch out for interactions that may be problematic.

Be Transparent: Behaving as though others can see your conduct is always a good policy. Anyone trying to maintain a public face that is markedly different from their private behavior is bound for epic failure in an age where online content is easily shared, and students have audio/video recording equipment with them at all times (on their mobile phones). An "abstinence-only" approach to social media is bound for failure just as much as the "abstinence-only" approach to reproductive health education. Content about you will go online whether or not you want it to - ultimately it's best to have a say in the conversation.

\section{IMPACTS ON SOCIAL MEDIA ON EDUCATION}

Some of the impacts on social media having on education are like this: [15]

1) It's free. In reality, nothing is really free. We still have to pay for Internet and technology in our building, but our software costs have gone down significantly. As educators continuously have to deal with budget cuts, it is important that we use tools that do not have a cost on it. Safety is essential, but with teaching Internet safety, setting up certain sites, with a little hard work, the software costs nothing.

2) It cuts down on isolation. There are some programs is an off-site building. Some of the program serves 12 students and has two teachers. Every few years, this program is revisited and they ensure that teachers have an opportunity to move so that they have the ability to connect and learn from others. They are both connected through many teachers through social networks and the feeling of isolation has somewhat dissipated.

3) Building tolerance and understanding of cultural 
diversity. There are so many different cultures in the world and we only had read about them in books. There is so much of an opportunity to not only read content from different people and hear their perspectives, but social media gives us the opportunity to actually talk with people. Having the opportunity to connect with people all over the world breaks down a lot of barriers and builds understanding. These are opportunities that we did not have as kids but we need to ensure that our students have this opportunity now.

4) It can amplify passion. Passion is a term that has been used a great deal in education. We have to build learning upon the passions and interests of the students. We now have the opportunity to not only connect with people of different cultures, but to people with similar interests. A student talks about through the use of video, dance has evolved so rapidly because of the ease of sharing. The child who does not feel anyone has similar interests in the classroom, is not limited anymore. We can help to facilitate these connections in schools so our students do not only feel "normal", but their passion thrives.

5) The world of education is (and needs to be) more open. We need to continuously communicate and connect with not only the stakeholders, but the world of education. Parents no longer need to wonder what a teacher is thinking, because he can share it continuously in an open way. He can do everything from sharing his calendar for the week with the classroom community. The parent, who may not know the teacher in the next grade, can simply follow their blog to get to know about some of the practices. This breaks down walls and helps to build relationships with families and our community. Parents could not see the other classroom's "newsletter" unless it was passed around; now it is easily shared. Knowing people beforehand will help to break down barriers that may have existed before.

Education is based upon relationships. While people often look at social media is just "technology" we have to see how proper use can help really bring our world together. If we are proactive in the way we work with kids using social media, there is no limit to what we can do.

\section{CONCLUSION}

While the technology is new, the issue of inappropriate, problematic and hurtful speech on campuses is not. For this reason institutions can generally rely on institutional precedent when responding to online speech. On the other hand, the proliferation and exponentially broader reach of online speech has prompted institutions to identify and create new ways of connecting with students about their behavior, methods that may be more effective than traditional judicial norms.

Needless to say, as new technologies develop, so will the related issues colleges must confront. It will be the responsibility of all university staff, including attorneys, to find creative and effective ways to address inappropriate online speech, the best of which will fall within institutions' educational missions.

\section{REFERENCES}

[1] M. A. Urista, Q. Dong, and K. D. Day, "Explaining why young adults use myspace and facebook through uses and gratifications theory," Human Communication, vol. 12, no. 2, pp. 215- 229, 2009

[2] D. M. Boyd and N. B. Ellison, "Social network sites: Definition, history, and scholarship," Journal of Computer Mediated Communication, vol. 13, pp. 210-230, 2007.

[3] Z. Tufekci, "Grooming, gossip, facebook, and myspace," Information, Communication \& Society, vol. 11, no. 4, pp. 544-564, 2008.

[4] C. Murray, "Schools and social networking: Fear or education?" Synergy Perspectives: Local, vol. 6, issue 1, pp. 8-12, 2008.

[5] H. R. Haverback, "Facebook: Uncharted territory in a reading education classroom," Reading Today, pp. 34, 2009.

[6] J. Peluchette and K. Karl, "Examining students' intended image on facebook: What were they thinking?" Journal of Education for Business, vol. 85, pp. 30-37, 2010.

[7] P. Pollara and J. Zhu, "Social networking and education: Using facebook as an edusocial space," in Proc. Society for Information Technology \& Teacher Education International Conference, Chesapeake, VA: AACE, 2011, pp. 3330-3338.

[8] R. Kern. (2010). 5 social media tools for college students. [Online]. Available:

http://www.usnews.com/education/articles/2010/05/12/5-social-media -tools-for-college-students.

[9] D. M. Burl. (2011). From Tinker to Twitter: Managing student speech on social media. [Online]. Available: http://counsel.cua.edu/studlife/publications/nacuanotesmarch16.cfm

[10] C. Madge, J. Meek, J. Wellens, and T. Hooley, "Facebook, social integration and informal learning at university: It is more for socialising and talking to friends about work than for actually doing work," Learning, Media and Technology, vol. 34, issue 2, pp. 141-155.

[11] J. K. Osborne. (2011). Social media and student discipline. [Online]. Available:

http://www.udallshumway.com/wp-content/uploads/2011/07/SocialMedia-and-Student-Discipline

[12] Counsel. (2014). [Online]. Available: http://counsel.cua.edu/studlife/publications/nacuanotesmarch16.cfm)

[13] J. Greer. (2010). 5 do's and don'ts for college students using social media. [Online]. Available: http://www.usnews.com/education/articles/2010/05/12/5-dos-and-don ts-for-college-students-using-social-media

[14] Devriesblog. (2011). Five Tips for faculty on interacting with students via social media. [Online]. Available: http://devriesblog.com/2011/02/28/five-tips-for-faculty-on-interacting -with-students-via-social-media

[15] G. Couros. (2011). [Online]. Available: http://connectedprincipals.com/archives/3024

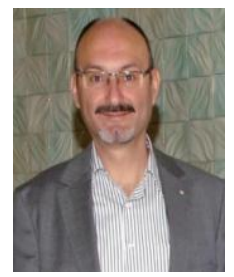

Halil Ibrahim Gurcan was born in 1988. He started to work in Anadolu University as a research assistant. In 1992, he received his master's degree from the University of Stirling at Scotland. He got his doctoral degree (Ph.D.) in communication sciences in 1996. He became an associated professor in 1999 and a professor in 2004 at Anadolu University, Faculty of Communication.

Currently, he is working as a full-time professor and the chair of the Department of Publishing Techniques at the Anadolu University Faculty of Communication Sciences.

Prof. Dr. Gurcan has written six books, 30 articles and 25 presentations at international and national symposiums and conferences which are about online journalism, social media, journalism, publishing technologies and book publishing. 